\title{
Response of Cucumber (Cucumis sativus L.) to Various Organic Fertilization Treatments under an Organig Farming System. El-Hamdi, Kh. H. ${ }^{1}$; A. A. Mosa ${ }^{1}$ : M. M. EL-Shazly ${ }^{2}$ and Noha R. Hashish ${ }^{1}$. ${ }^{1}$ Soils Department, Faculty of Agriculture, Mansoura University. \\ ${ }^{2}$ Soil, Water and Environment Institute, Agriculture Research Center.
}

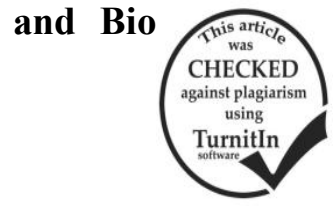

\section{ABSTRACT}

A pot experiment was conducted outdoor at the Experimental Farm, Faculty of Agriculture, Mansoura University during the summer seasons of 2015 and 2016.to evaluate the positive interaction effects among different types of organic fertilization forms and levels alongside with bio fertilizer applications on quantitative and qualitative yield characteristics of cucumber grown under an organic farming conditions.. Thirty treatments were arranged in a split-split plot design with three replicates, which were the simple combination of three types of organic amendments (compost, FYM, and biochar), two rates of soil application ( 5 and 10 ton $\left.\mathrm{fed}^{-1}\right)$ and five types of bio fertilizer application forms i.e. (1) microbien + phosphorien, (2) microbien + phosphorien+ effective microorganisms (EM), (3) EM, (4) poultry manure extract, and (5) control (without biofertilizetion). Compost proved its effectiveness in improving yield characteristics, nutrients content and quality indices as compared with other organic amendments. The application level of 10 ton $\mathrm{fed}^{-1}$ was the optimum rate for providing sufficient needs of plant during its whole growth stage. The combined biofertilization treatment (microbien + phosphosien+ EM) was the most effective treatment for improving quantitative and qualitative yield characteristics. The obtained results concluded that the

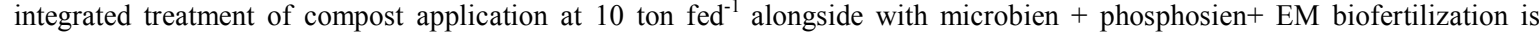
recommended to produce the highest productivity and quality indices of cucumber yield grown on a sandy soil condition.

Keywords: Cucumber (Cucumis sativus L.), organic fertilization, bio fertilizers, nutrient contents, fruit quality and sandy soils.

\section{INTRODUCTION}

The future sustainable agriculture should focus on producing sufficient yield (food, feed and fiber) to satisfy changing human needs with conserving natural resources, maintaining the quality of the environment, and ultimately leading to community and gender equity (Dimitri et al., 2012). Recently, attention has been directed toward expansion in organic farming to cope with sustainable agriculture needs. Organic farming is the production system where synthetic fertilizers, pesticides and growth regulators are completely or largely avoided. Organic farming systems are growing rapidly in the last decades (approximately 31 million hectares worldwide) with annual revenues of about 26 billion \$ (Ashraf et al., 2016). Organic farming growers have to market their production in high prices to compensate the low-productivity of organic farming systems as compared with conventional production. The consumers of organic production, therefore, are affluent educated and health conscious have the willingness to pay for the high-priced products (Yadav et al., 2013). Consequently, there is an urgent need to produce organic crops with high profitability and quality in order to provide organic products with lower prices available for various categories of consumers. This could be achieved through maximizing the nutritive value of organic amendments to generate high yield production.

Composting is a natural way to rejuvenate the soil health. Compost recycles nutrient elements (e.g. C, N, K, $\mathrm{Mg}, \mathrm{S}, \mathrm{P}$ and micronutrients) into the rhizosphere. These essential nutrients not only sustain the plants nutrition needs, but also provide an available form for feeding soil microorganisms. Farmyard manure (FYM) is the most used conventional manure in most worldwide agricultural systems. It is a decomposed mixture of cattle dung and urine with agricultural residues (e.g. rice straw), which used as bedding and/or a feeding material (Belay et al., 2001). FYM releases plant nutrients slowly and steadily and activates soil microbial biomass (Ayuso et al., 1996). On the other hand, attention has been drawn recently toward using biochar in organic farming systems. Biochar is the recalcitrant carbonized material generated following thermal processing of organic biomass in oxygen limited conditions (Downie et al., 2009).

Biofertilizers can be defined as the living cells of efficient strains of nitrogen fixers, phosphate solubilizes and silicate decomposers used for application to soil with the objective of acceleration certain microbial processes to augment the extent of the availability of nutrients in a form which can be easily assimilated by plants (Cakmakci et al., 1999 and Abu El-Fotoh et al., 2000). In addition to their crucial role in nutrients availability,biofertilizers produce organic acids, which protects plant against plant pathogens and excretion growth regulators like IAA and GA3. Effective Micro-organisms (EM) as a biofertilizer contains group of beneficial microorganisms (primary photosynthetic and lactic acid bacteria, yeast, actinomycetes and fermenting fungi) which promotes germination, flowering, fruit and ripening, improves physical, chemical and biological environments of the soil and suppresses soil borne pathogens and pests. Furthermore, it enhances the photosynthetic capacity of crops (Woodward, 2003).

Cucumber (Cucumis sativus L.) is a member of the economically important family cucurbitaceae. Cucumber is a warm season crop. However, it has the ability to grow under very wide range of climates either in open fields or in greenhouses. In Egypt, cucumber is grown in open fields at the summer season and under greenhouses or plastic tunnels in winter season.

The objectives of this work are to evaluate the positive interaction effects among different types of organic fertilization forms and levels alongside with bio fertilizers applications on quantitative and qualitative yield characteristics of cucumber grown under sandy soil conditions.

\section{MATERIALS AND METHODS}

A pot experiment was conducted in outdoor conditions at the Experimental Farm, Faculty of Agriculture, Mansoura University during the summer seasons of 2015 and 2016 to investigate the impact of organic fertilizers (compost, farmyard manure (FYM) and biochar) with two 
rates (5 and $10 \mathrm{Mg} \mathrm{fed}^{-1}$ ) and bio fertilizers (Microbien, phesphorien, EM and poultry manure extract) application on maximizing productivity of cucumber (Cucumis sativus L.) grown in a sandy soil. Thirty treatments, which represent the simple combination between treatments, were arranged in a split-split plot design with three replicates. Experimental pots $\left(10 \mathrm{~g} \mathrm{pot}^{-1}\right)$ were irrigated to reach the field capacity, and the assumed field capacity were compensated every 3-4 days with tap water by weight. Biofertilizers were applied before first irrigation directly by mixing their recommended dose) with soil. Plants were sown at mid of June in both seasons ( 5 seed per each pot). Two weeks later; seedling were thinned to the most two uniform ones per pot. Some soil physical and chemical analyses , the available $\mathrm{Fe}, \mathrm{Zn}, \mathrm{Cu}$, and $\mathrm{Mn}$ were determined as described by (Ryan 1996; Table 1)

Table 1. Some physical and chemical properties of the experimental soil before cultivations in the two Seasons.

\begin{tabular}{|c|c|c|c|}
\hline Soil properties & & $\begin{array}{c}2015- \\
2016\end{array}$ & $\begin{array}{l}2016- \\
2017\end{array}$ \\
\hline \multirow{7}{*}{$\begin{array}{l}\text { Mechanical } \\
\text { analysis }\end{array}$} & Coarse sand $\%$ & 6.75 & 7.01 \\
\hline & Fine sand $\%$ & 68.47 & 69.31 \\
\hline & Silt \% & 15.66 & 15.34 \\
\hline & Clay $\%$ & 9.12 & 8.34 \\
\hline & Soil texture & Sandy & Sandy \\
\hline & Organic matter $\%$ & 0.98 & 0.92 \\
\hline & $\begin{array}{c}\text { Saturation percentage } \\
\% \%\end{array}$ & 29.5 & 31.0 \\
\hline \multicolumn{4}{|c|}{ Chemical properties } \\
\hline \multirow{4}{*}{$\begin{array}{l}\mathrm{CaCO}_{3} \% \\
\mathrm{pH} \\
\mathrm{EC}\left(\mathrm{dSm}^{-1}\right)(1: 5)\end{array}$} & & 4.63 & 4.52 \\
\hline & & 8.13 & 7.89 \\
\hline & & 1.09 & 0.98 \\
\hline & $\mathrm{CO}_{3}{ }^{2-}$ & N.D & N.D \\
\hline \multirow{4}{*}{$\begin{array}{l}\text { Anions } \\
\text { (meq } 100 \mathrm{~g}^{-1} \text { soil) }\end{array}$} & $\mathrm{HCO}_{3}^{-}$ & 1.19 & 1.01 \\
\hline & $\mathrm{Cl}^{-}$ & 2.63 & 2.55 \\
\hline & $\mathrm{SO}_{4}^{-2}$ & 1.76 & 1.45 \\
\hline & $\mathrm{Ca}^{4}$ & 1.69 & 1.43 \\
\hline \multirow{3}{*}{$\begin{array}{l}\text { Cations } \\
\text { (meq } 100 \mathrm{~g}^{-1} \text { soil) }\end{array}$} & $\mathrm{Mg}^{+2}$ & 0.98 & 0.95 \\
\hline & $\mathrm{Na}^{+}$ & 2.77 & 2.55 \\
\hline & $\mathrm{K}^{+}$ & 0.14 & 0.08 \\
\hline \multirow{3}{*}{$\begin{array}{l}\text { Available } \\
\text { Nutrient } \\
\left(\mathrm{mg} \mathrm{kg}^{-1} \text { soil) }\right.\end{array}$} & $\mathrm{N}$ & 37.9 & 38.23 \\
\hline & $\mathrm{P}$ & 3.95 & 3.56 \\
\hline & $\mathrm{K}$ & 194 & 201 \\
\hline \multirow{3}{*}{$\begin{array}{l}\text { Micronutrient } \\
\left(\mathrm{mg} \mathrm{kg}^{-1} \text { soil }\right)\end{array}$} & $\mathrm{Fe}$ & 4.5 & 4.2 \\
\hline & $\mathrm{Mn}$ & 2.98 & 2.87 \\
\hline & $\mathrm{Zn}$ & 0.45 & 0.39 \\
\hline
\end{tabular}

N.D. means not detected

Mature compost and biochar were obtained from a private farm located at Belquas District, Dakahlia Governorate. FYM was obtained from the Animal husbandry farm, Mansoura University. Some chemical properties of the used organic amendments, biochar and poultry manure extract are presented in Table 2,3 and 4 .

At harvesting stage (60 days from sowing), vegetative growth and yield parameters (average fruit weight $(\mathrm{g})$, total yield per pot and number of fruits per pot) were recorded. To carry out chemical analysis of fruits, random samples were selected from each treatment, oven dried at $70^{\circ} \mathrm{C}$, ground and wet digested by the acid mixture of $\mathrm{H}+\mathrm{SO}_{4}$ and $\mathrm{HClO}_{4}$ (Peterburgski 1968). Using standard Kjeldahl method, total nitrogen was determined according to Hesse (1971). Phosphorus was calorimetrically determined at wavelength of 680 nm (Jackson, 1967). According to Black (1965), potassium was determined using flame photometer.
Table 2. Some chemical properties of the organic manures used:-

\begin{tabular}{|c|c|c|c|c|}
\hline \multirow{2}{*}{ Sample } & \multicolumn{2}{|c|}{ Season 1} & \multicolumn{2}{|c|}{ Season 2} \\
\hline & FYM & Compost & FYM & Compost \\
\hline O.M \% & 35.75 & 37.20 & 49.2 & 57.6 \\
\hline O.C $\%$ & 20.62 & 25.05 & 28.6 & 33.5 \\
\hline $\mathrm{N} \%$ & 1.19 & 2.07 & 1.48 & 2.12 \\
\hline $\mathrm{P} \%$ & 0.41 & 0.55 & 0.36 & 0.41 \\
\hline K \% & 0.55 & 0.63 & 0.49 & 0.57 \\
\hline $\mathrm{C} / \mathrm{N}$ & 17.32 & 12.10 & 19.3 & 15.8 \\
\hline $\mathrm{pH}$ & 6.56 & 6.02 & 6.57 & 6.09 \\
\hline E.C dSm ${ }^{-1}$ & 3.97 & 3.57 & 4.15 & 3.79 \\
\hline $\mathrm{SP} \%$ & 135 & 157 & 132.5 & 149.7 \\
\hline
\end{tabular}

Table 3. Chemical characteristics of the biochar used:-

\begin{tabular}{lc}
\hline Sample & Biochar \\
\hline Moisture & $14.01 \%$ \\
$\mathrm{pH}$ & 9.6 \\
$\mathrm{C}$ & $77.4 \%$ \\
Total nitrogen & $0.87 \%$ \\
$\mathrm{C} / \mathrm{N}$ & 88.9 \\
$\mathrm{Cu} \mathrm{mg} \mathrm{kg}$ & -1 \\
$\mathrm{Fe} \mathrm{mg} \mathrm{kg}$ & 94 \\
$\mathrm{Mn} \mathrm{mg} \mathrm{kg}$ & 326 \\
$\mathrm{Zn} \mathrm{mg} \mathrm{kg}^{-1}$ & 81 \\
$\mathrm{P} \mathrm{g} \mathrm{kg}^{-1}$ & 99 \\
$\mathrm{~K} \mathrm{~g} \mathrm{~kg}^{-1}$ & 20.5 \\
\hline
\end{tabular}

Table 4. Chemical analyses of the poultry manure extract:

\begin{tabular}{|c|c|}
\hline Sample $\left(\mathrm{mg} \mathrm{L}^{-1}\right)$ & poultry manure extract \\
\hline $\mathrm{N}$ & 89.6 \\
\hline $\mathrm{P}$ & 19.3 \\
\hline K & 435.2 \\
\hline $\mathrm{Fe}$ & 32.6 \\
\hline $\mathrm{Zn}$ & 7.95 \\
\hline $\mathrm{Mn}$ & 16.09 \\
\hline
\end{tabular}

Representative samples of cucumber fruits were randomly chosen from each treatment at the third picking to determine the quality parameters of cucumber fruits (i.e. total soluble solids (TSS) using a hand refractometer and free $\mathrm{NO}_{3}-\mathrm{N}\left(\mathrm{mg} \mathrm{kg}^{-1}\right)$ according to the method described by Singh (1988)).

All statistical analyses were performed using analysis of variance technique by means of COSTATE Computer Software (V. 6.303, CoHort, USA, 19982004) as described by Gomez and Gomez, (1984). Treatment means were compared using Duncan's multiple range test at the $5 \%$ level of probability.

\section{RESULTS AND DISCUSSION}

\section{Fruit yield and its components:}

Data presented in Table 5 illustrate the effect of organic fertilizers types, organic fertilizers levels, bio fertilizers types and their interactions on average fruit weight $(\mathrm{g})$, fruit length $(\mathrm{cm})$, No. of fruits $\operatorname{pot}^{-1}$ and total yield $g$ pot $^{-1}$ during both seasons of experiment.

The statistical analysis of obtained data show that organic fertilizers types had a significant effect on average fruit weight $(\mathrm{g})$, fruit length $(\mathrm{cm})$, No. of fruits pot $^{-1}$ and total yield pot ${ }^{-1}$ in (Table 5). It can be observed that compost fertilizer treatment caused a progressive increase in all characters over than FYM and biochar treatments. This is mainly revealed to the positive impact of compost on physical and chemical properties of soil comparing with other organic fertilizers. Several reports suggested that compost has a significant impact on improves soil drainage, and maximizing water and 
nutrient supply potentials of soil; thus, maintain cucumber productivity ( Kabeel and Hasanin (2006); Polat et al. (2009); Nair and Ngouajio (2010); Fahmy (2012) and Abou-El-Hassan et al. (2014)). Further to this, the chemical analysis of organic amendments illustrated that compost has a lower $\mathrm{C} / \mathrm{N}$ ratio as compared with other treatments, which allowed the readily flux of available nitrogen for plants grown under compost treatments. On other hand, the lowest vegetative growth values were recorded with plants amended with biochar in both seasons. This is mainly revealed to the low nutritive values of biochar as compared with compost and FYM.

Table 5. Fruits weight (g), fruit length (cm), No. of fruits pot $^{-1}$ and total yield pot ${ }^{-1}$ of cucumber plants as affected by organic fertilizers types, organic fertilizers levels and bio fertilizers types in 2015 and 2016 seasons.

\begin{tabular}{|c|c|c|c|c|c|c|c|c|c|}
\hline \multirow{2}{*}{\multicolumn{2}{|c|}{ Treatments }} & \multicolumn{2}{|c|}{ Fruit weight (g) } & \multicolumn{2}{|c|}{ Fruit length $(\mathrm{cm})$} & \multicolumn{2}{|c|}{ No. of fruits } & \multicolumn{2}{|c|}{ Total yield $\left(\mathrm{g} \mathrm{pot}^{-1}\right)$} \\
\hline & & & & & sea & & & & \\
\hline O.F. O. F. levels & Bio fertilizers & 2015 & 2016 & 2015 & 2016 & 2015 & 2016 & 2015 & 2016 \\
\hline \multirow{5}{*}{5 ton $\mathrm{fed}^{-1}$} & 0 & $37.53 \mathrm{p}$ & $8.15 \mathrm{k}$ & $10.66 \mathrm{i}$ & $401.2 \mathrm{k}$ & $37.03 \mathrm{t}$ & 8.50 & $12.66 \mathrm{i}$ & $465.00 \mathrm{n}$ \\
\hline & $\mathrm{M}+\mathrm{ph}$ & 39.93 & $8.86 \mathrm{~g}$ & $12.66 \mathrm{f}$ & $505.8 \mathrm{f}$ & $41.86 \mathrm{f}$ & $9.52 \mathrm{ef}$ & $14.66 \mathrm{f}$ & $614.46 \mathrm{~h}$ \\
\hline & $\mathrm{EM}+\mathrm{M}+\mathrm{ph}$ & $42.16 \mathrm{~b}$ & $9.65 \mathrm{~b}$ & $16.00 \mathrm{~b}$ & $674.66 \mathrm{~b}$ & $44.20 \mathrm{~b}$ & $10.23 \mathrm{~b}$ & $18.00 \mathrm{~b}$ & $795.60 \mathrm{~b}$ \\
\hline & EM & $40.90 \mathrm{e}$ & $9.23 \mathrm{~d}$ & $14.00 \mathrm{~d}$ & $572.20 \mathrm{~d}$ & $44.20 \mathrm{~b}$ & $9.74 \mathrm{~d}$ & $16.00 \mathrm{~d}$ & $706.93 \mathrm{~d}$ \\
\hline & PME & 38.631 & $8.49 \mathrm{i}$ & $12.00 \mathrm{~g}$ & $463.60 \mathrm{~h}$ & $41.53 \mathrm{~h}$ & $8.99 \mathrm{~h}$ & $14.00 \mathrm{~g}$ & $581.46 \mathrm{i}$ \\
\hline \multirow{5}{*}{10 ton $\mathrm{fed}^{-1}$} & 0 & $38.13 \mathrm{mn}$ & $8.31 \mathrm{j}$ & $11.33 \mathrm{~h}$ & $431.73 \mathrm{j}$ & $41.00 \mathrm{j}$ & $8.92 \mathrm{~h}$ & $13.33 \mathrm{~h}$ & $546.26 \mathrm{j}$ \\
\hline & $\mathrm{M}+\mathrm{ph}$ & $40.46 \mathrm{~g}$ & $9.05 \mathrm{e}$ & $14.00 \mathrm{~d}$ & $566.53 \mathrm{~d}$ & $43.06 \mathrm{~d}$ & $9.59 \mathrm{e}$ & $16.00 \mathrm{~d}$ & $689.06 \mathrm{e}$ \\
\hline & $\mathrm{EM}+\mathrm{M}+\mathrm{ph}$ & $42.53 \mathrm{a}$ & $9.85 \mathrm{a}$ & $16.66 \mathrm{a}$ & $709.26 \mathrm{a}$ & $45.23 \mathrm{a}$ & $10.38 \mathrm{a}$ & $18.66 \mathrm{a}$ & $844.4 \mathrm{a}$ \\
\hline & EM & $41.46 \mathrm{c}$ & $9.45 \mathrm{c}$ & $14.66 \mathrm{c}$ & $608.20 \mathrm{c}$ & $43.46 \mathrm{c}$ & $10.01 \mathrm{c}$ & $16.66 \mathrm{c}$ & $724.73 \mathrm{c}$ \\
\hline & PME & $39.13 \mathrm{j}$ & $8.73 \mathrm{~h}$ & $12.00 \mathrm{~g}$ & $470.06 \mathrm{gh}$ & $41.70 \mathrm{~g}$ & $9.25 \mathrm{~g}$ & $14.00 \mathrm{~g}$ & $583.93 \mathrm{i}$ \\
\hline \multirow{5}{*}{5 ton $\mathrm{fed}^{-1}$} & 0 & $35.83 \mathrm{u}$ & $7.09 \mathrm{~s}$ & $7.33 \mathrm{n}$ & $263.06 \mathrm{p}$ & $37.60 \mathrm{r}$ & 7.48 op & $9.33 \mathrm{n}$ & $350.53 \mathrm{r}$ \\
\hline & $\mathrm{M}+\mathrm{ph}$ & $38.06 \mathrm{n}$ & 7.951 & $10.00 \mathrm{j}$ & 380.661 & $40.56 \mathrm{k}$ & $8.42 \mathrm{k}$ & $12.00 \mathrm{j}$ & $486.80 \mathrm{~m}$ \\
\hline & $\mathrm{EM}+\mathrm{M}+\mathrm{ph}$ & $40.60 \mathrm{f}$ & $8.73 \mathrm{~h}$ & $12.66 \mathrm{f}$ & $514.73 \mathrm{f}$ & $43.56 \mathrm{c}$ & $9.33 \mathrm{~g}$ & $14.66 \mathrm{f}$ & $638.73 \mathrm{~g}$ \\
\hline & EM & $39.36 \mathrm{i}$ & $8.29 \mathrm{j}$ & $11.33 \mathrm{~h}$ & $446.66 \mathrm{i}$ & $41.26 \mathrm{i}$ & $8.78 \mathrm{i}$ & $13.33 \mathrm{~h}$ & $549.73 \mathrm{j}$ \\
\hline & PME & $36.93 \mathrm{r}$ & $7.47 \mathrm{o}$ & 8.661 & $320.46 \mathrm{n}$ & 39.761 & $7.92 \mathrm{~m}$ & 10.661 & $424.33 \mathrm{p}$ \\
\hline \multirow{5}{*}{10 ton $\mathrm{fed}^{-1}$} & 0 & $36.23 \mathrm{t}$ & $7.27 \mathrm{q}$ & $8.00 \mathrm{~m}$ & 289.86 o & $38.00 \mathrm{q}$ & $7.71 \mathrm{n}$ & $10.00 \mathrm{~m}$ & $380.00 \mathrm{q}$ \\
\hline & $\mathrm{M}+\mathrm{ph}$ & $38.73 \mathrm{k}$ & $8.12 \mathrm{k}$ & $10.66 \mathrm{i}$ & $413.13 \mathrm{k}$ & $40.60 \mathrm{k}$ & $8.53 \mathrm{j}$ & $12.66 \mathrm{i}$ & 513.661 \\
\hline & $\mathrm{EM}+\mathrm{M}+\mathrm{ph}$ & $41.10 \mathrm{~d}$ & $8.92 \mathrm{f}$ & $13.33 \mathrm{e}$ & $548.00 \mathrm{e}$ & $43.06 \mathrm{~d}$ & $9.45 \mathrm{f}$ & $15.33 \mathrm{e}$ & $660.60 \mathrm{f}$ \\
\hline & EM & $39.96 \mathrm{~h}$ & $8.51 \mathrm{i}$ & $12.00 \mathrm{~g}$ & $479.50 \mathrm{~g}$ & $42.23 \mathrm{e}$ & $9.01 \mathrm{~h}$ & $14.00 \mathrm{~g}$ & $591.26 \mathrm{i}$ \\
\hline & PME & $37.30 \mathrm{q}$ & $7.71 \mathrm{~m}$ & $9.33 \mathrm{k}$ & $348.06 \mathrm{~m}$ & 39.13 о & 8.171 & $11.33 \mathrm{k}$ & 443.66 o \\
\hline \multirow{10}{*}{ 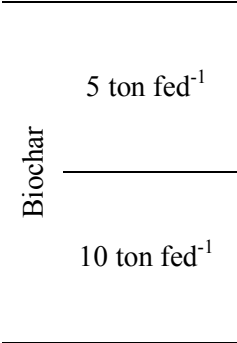 } & 0 & $33.50 \mathrm{z}$ & $5.82 \mathrm{z}$ & $4.66 \mathrm{r}$ & $155.93 \mathrm{t}$ & $35.16 \times$ & $6.16 \mathrm{v}$ & $6.66 \mathrm{r}$ & $233.80 \mathrm{v}$ \\
\hline & $\mathrm{M}+\mathrm{ph}$ & $35.46 \mathrm{v}$ & $6.55 \mathrm{v}$ & $7.33 \mathrm{n}$ & $260.00 \mathrm{p}$ & $37.20 \mathrm{~s}$ & $6.85 \mathrm{r}$ & $9.33 \mathrm{n}$ & $346.66 \mathrm{r}$ \\
\hline & $\mathrm{EM}+\mathrm{M}+\mathrm{ph}$ & 37.73 o & $7.33 \mathrm{p}$ & $10.00 \mathrm{j}$ & 377.331 & $39.56 \mathrm{~m}$ & $7.76 \mathrm{n}$ & $12.00 \mathrm{j}$ & $474.80 \mathrm{mn}$ \\
\hline & EM & $36.73 \mathrm{~s}$ & $7.00 \mathrm{t}$ & 8.661 & $318.66 \mathrm{n}$ & $38.53 \mathrm{p}$ & $7.42 \mathrm{p}$ & 10.661 & $411.53 \mathrm{p}$ \\
\hline & PME & $34.56 \mathrm{x}$ & $6.18 \mathrm{x}$ & $6.00 \mathrm{p}$ & 207.40 & $35.96 \mathrm{v}$ & $6.55 \mathrm{t}$ & $8.00 \mathrm{p}$ & $287.73 \mathrm{t}$ \\
\hline & 0 & $34.00 \mathrm{y}$ & $5.98 \mathrm{y}$ & $5.33 \mathrm{q}$ & $181.40 \mathrm{~s}$ & $35.70 \mathrm{w}$ & $6.33 \mathrm{u}$ & $7.33 \mathrm{q}$ & $261.40 \mathrm{u}$ \\
\hline & $\mathrm{M}+\mathrm{ph}$ & $36.20 \mathrm{t}$ & $6.75 \mathrm{u}$ & $8.00 \mathrm{~m}$ & 289.60 & $37.63 \mathrm{r}$ & $7.15 \mathrm{q}$ & $10.00 \mathrm{~m}$ & $376.33 \mathrm{q}$ \\
\hline & $\mathrm{EM}+\mathrm{M}+\mathrm{ph}$ & $38.20 \mathrm{~m}$ & $7.54 \mathrm{n}$ & $11.33 \mathrm{~h}$ & $432.80 \mathrm{j}$ & 39.731 & $7.98 \mathrm{~m}$ & $13.33 \mathrm{~h}$ & $529.66 \mathrm{k}$ \\
\hline & EM & $37.26 \mathrm{q}$ & $7.14 \mathrm{r}$ & $9.33 \mathrm{k}$ & $347.80 \mathrm{~m}$ & $39.43 \mathrm{n}$ & $7.56 \mathrm{o}$ & $11.33 \mathrm{k}$ & $447.00 \mathrm{o}$ \\
\hline & PME & $35.06 \mathrm{w}$ & $6.35 \mathrm{w}$ & $6.66 \mathrm{o}$ & $233.40 \mathrm{q}$ & $36.13 \mathrm{u}$ & $6.73 \mathrm{~s}$ & $8.66 \mathrm{o}$ & $313.40 \mathrm{~s}$ \\
\hline \multirow{3}{*}{$\begin{array}{l}\text { Mean values as } \\
\text { affected by organic } \\
\text { fertilizers }\end{array}$} & Compost & $40.09 \mathrm{a}$ & $8.97 \mathrm{a}$ & $13.4 \mathrm{a}$ & $540.32 \mathrm{a}$ & $42.33 \mathrm{a}$ & $9.51 \mathrm{a}$ & $15.4 \mathrm{a}$ & $655.18 \mathrm{a}$ \\
\hline & FYM & $38.41 \mathrm{~b}$ & $8.00 \mathrm{~b}$ & $10.33 \mathrm{~b}$ & $400.42 \mathrm{~b}$ & $40.58 \mathrm{~b}$ & $8.48 \mathrm{~b}$ & $12.33 \mathrm{~b}$ & $503.93 \mathrm{~b}$ \\
\hline & Biochar & $35.87 \mathrm{c}$ & $6.66 \mathrm{c}$ & $7.73 \mathrm{c}$ & $280.43 \mathrm{c}$ & $37.50 \mathrm{c}$ & $7.05 \mathrm{c}$ & $9.73 \mathrm{c}$ & $368.23 \mathrm{c}$ \\
\hline \multirow{2}{*}{$\begin{array}{l}\text { Mean v } \\
\text { affected } \\
\text { levels }\end{array}$} & 5 Ton $\mathrm{fed}^{-1}$ & $37.86 \mathrm{~b}$ & $7.78 \mathrm{~b}$ & $10.13 \mathrm{~b}$ & $390.82 \mathrm{~b}$ & $39.86 \mathrm{~b}$ & $8.24 \mathrm{~b}$ & $12.13 \mathrm{~b}$ & $491.20 \mathrm{~b}$ \\
\hline & 10 Ton $\mathrm{fed}^{-1}$ & $38.38 \mathrm{a}$ & $7.97 \mathrm{a}$ & $10.84 \mathrm{a}$ & 423.29 a & $40.40 \mathrm{a}$ & $8.45 \mathrm{a}$ & $12.84 \mathrm{a}$ & $527.02 \mathrm{a}$ \\
\hline \multirow{5}{*}{$\begin{array}{l}\text { Mean values as } \\
\text { affected by bio } \\
\text { fertilizers }\end{array}$} & Control & $35.87 \mathrm{e}$ & $7.10 \mathrm{e}$ & $7.88 \mathrm{e}$ & $287.2 \mathrm{e}$ & $37.41 \mathrm{e}$ & $7.52 \mathrm{e}$ & $9.88 \mathrm{e}$ & $372.83 \mathrm{e}$ \\
\hline & $\mathrm{M}+\mathrm{ph}$ & $38.14 \mathrm{c}$ & $7.87 \mathrm{c}$ & $10.44 \mathrm{c}$ & $402.62 \mathrm{c}$ & $40.15 \mathrm{c}$ & $8.34 \mathrm{c}$ & $12.44 \mathrm{c}$ & $504.50 \mathrm{c}$ \\
\hline & $\mathrm{EM}+\mathrm{M}+\mathrm{ph}$ & $40.38 \mathrm{a}$ & $8.66 \mathrm{a}$ & $13.33 \mathrm{a}$ & $542.8 \mathrm{a}$ & $42.56 \mathrm{a}$ & $9.19 \mathrm{a}$ & $15.33 \mathrm{a}$ & $657.30 \mathrm{a}$ \\
\hline & EM & $39.28 \mathrm{~b}$ & $8.26 \mathrm{~b}$ & $11.66 \mathrm{~b}$ & $462.18 \mathrm{~b}$ & $41.52 b$ & $8.75 \mathrm{~b}$ & $13.66 \mathrm{~b}$ & $571.86 \mathrm{~b}$ \\
\hline & PME & $36.93 \mathrm{~d}$ & $7.49 \mathrm{~d}$ & $9.11 \mathrm{~d}$ & $340.5 \mathrm{~d}$ & $39.03 \mathrm{~d}$ & $7.93 \mathrm{~d}$ & $11.11 \mathrm{~d}$ & $439.08 \mathrm{~d}$ \\
\hline
\end{tabular}

It can be noticed that the level of 10 ton fed $^{-1}$ significantly produced the highest mean values of all parameters i.e. average fruit weight, fruit length, No. of fruits per pot and total yield by $1.4,2.4,7.0$ and $8.3 \%$, respectively as compared with 5 ton $\mathrm{fed}^{-1}$ in the two growing seasons. Presumably, due to the insufficient nutrient contents of plant nutrients released under the level of 5 ton $\mathrm{fed}^{-1}$ (Mahmoud et al., 2009).
The statistical analysis showed a superiority for the combined treatment of bioertilizers $(\mathrm{EM}+\mathrm{M}+\mathrm{ph})$ comparing with sole application or the control treatment (without biofertilization). This combined biofertilizers contain effective microorganisms, which are able to play beneficial roles in improving soil quality indices (woodward, 2003). Several reports suggested the beneficial effect of biofertilization on improving 
cucumber productivity (Saeed et al., (2015) and Moemenpour and Karami (2015).

The interaction effect between treatments recorded significant effect on some vegetative growth parameters. The optimum treatment that generated the highest yield was compost application at 10 ton $^{\mathrm{fed}^{-1}}$ with the combined $(\mathrm{EM}+\mathrm{M}+\mathrm{ph})$ application. Beside the aforementioned benefits of biofertilizers on improving soil quality indices, it is well known that these microorganisms are able to accelerate the organic amendments decomposition; thus, releasing more nutrients for plant needs (Saleh et al., 2007)

$\mathrm{N}, \mathrm{P}, \mathrm{K}$ content $(\%)$, TSS\% and $\mathrm{NO}_{3}-\mathrm{N}$ ppm of cucumber plant.

Regarding the effect of organic fertilizers types on chemical compostion of cucumber fruits, it is clearly obvious that organic fertilizer types significantly affect $\mathrm{N}, \mathrm{P}$ and $\mathrm{K}$ content $(\%), \mathrm{TSS} \%$ and $\mathrm{NO}_{3}-\mathrm{N}$ ppm (Table 6) during both seasons . An obvious superiority was recorded for compost treatment in maximizing nutrient concentrations in cucumber fruits.

Table 6. N, P, K, TSS (\%) and $\mathrm{No}_{3}-\mathrm{N}\left(\mathrm{mg} \mathrm{kg}^{-1}\right)$ of cucumber plants as affected by organic fertilizers types, organic fertilizers levels and bio fertilizers types in 2015 and 2016 seasons.

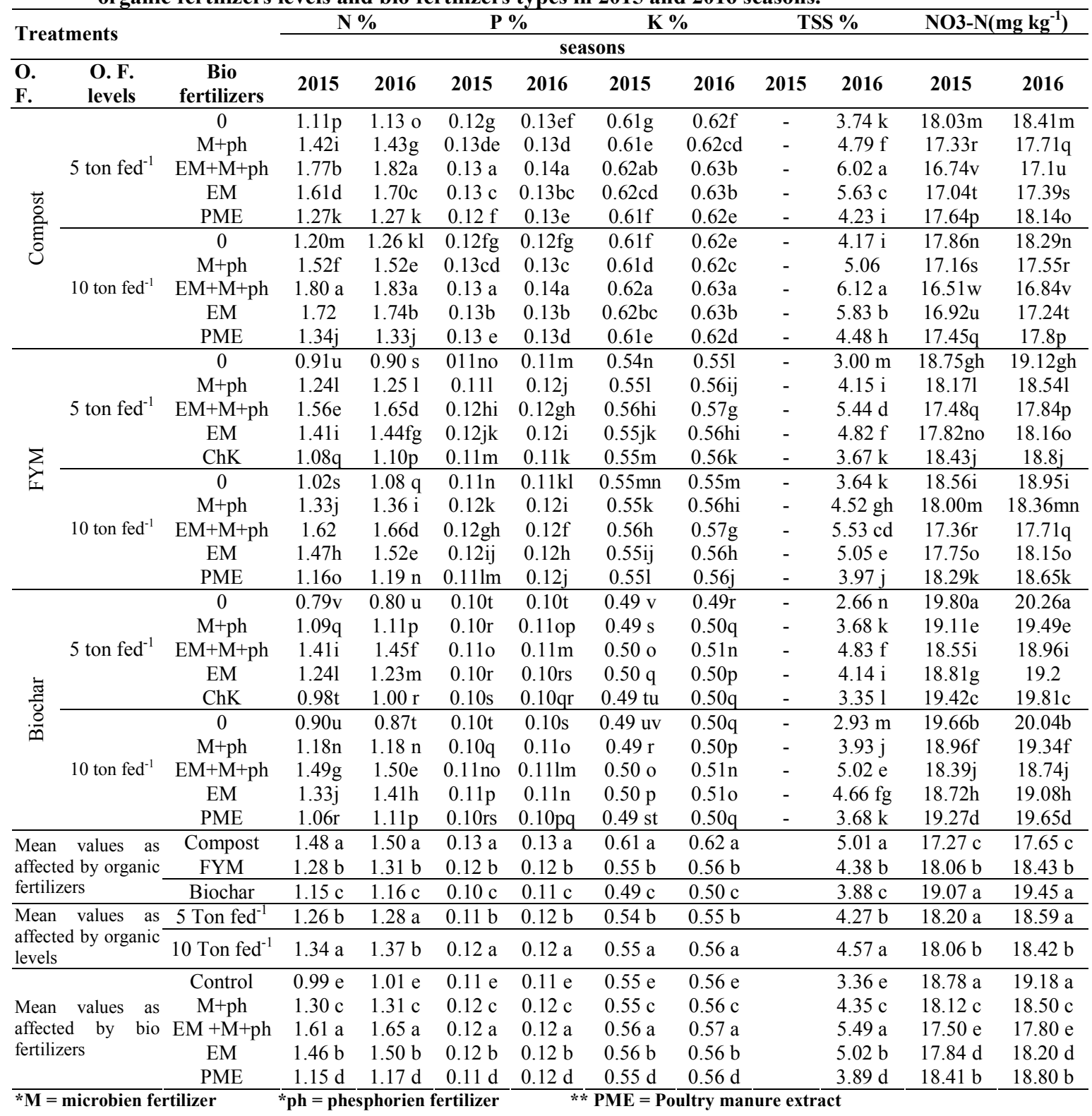

These results may be attributed to the role of compost in soil quality properties as it produces humic substances, which are able to improve some physical and chemical soil properties leading to increasing nutrient availabilities. Moreover, incorporation of organic materials in soils can further increase NPK availability by increasing $\mathrm{CO}_{2}$ forming $\mathrm{H}_{2} \mathrm{CO}_{3}$ in the soil solution. Also, improvement of these parameters may be due to the slow and continuous supply of both micro and macro nutrients, which might have helped in the assimilation of carbohydrates. These trend of result could be enhanced with those obtained by Kabeel and 
Hasanin (2006), Talha (2013), Natsheh and Mousa (2014).

Concerning the effect of organic fertilizer rate, it is cleared that the application level of 10 ton $\mathrm{fed}^{-1}$ gave the highest nutrient concentration as compared with 5 ton $\mathrm{fed}^{-1}$. This might be attributed the fact that the rate of 10 ton $\mathrm{fed}^{-1}$ was able to satisfy plant nutrient needs during the whole growth season.

The combined biofertilization treatment $(\mathrm{EM}+\mathrm{M}+\mathrm{ph})$ recorded the highest value of plant nutrients. This result may be due to the beneficial effect of dual application on macronutrients availability and uptake by plants. These results confirm by those obtained by Rashed (2002) who reported that biofertilizers combined with organic manure increased the content of nitrogen, phosphorus and potassium. ElGhadban et al (2002) mentioned that both compost and biofertilizers led to an increase of macro-nutrients uptake. This increase might be related to the positive effect of compost and microorganisms in increasing the root surface area per unit of soil volume and water-use efficiency, which directly affects the physiological processes and nutrients absorption. Inoculated plants with biofertilizers combined with full dose of compost gave the highest uptake of total nitrogen, phosphorus and potassium. These results are in harmony with those obtained by Han et al. (2006), Isfahani and Besharati (2012), Moemenpour and Karami (2015) for Nitrobin and Phosphorin as well as Arafa et al. (2012), Abd ElHameed (2013) and Olle (2015) for EM

As shown in Table 6, the interaction effects between all treatments have significant differences during the two seasons. The interaction between organic fertilizers types $\times$ organic fertilizers levels is significant on $\mathrm{N}, \mathrm{P}, \mathrm{K}$ contents, TSS\% and $\mathrm{NO}_{3}-\mathrm{N}$ in fruit of cucumber plant. The same trend was true in the $2^{\text {nd }}$ season. The optimum treatment that produced the highest values under investigation in fruits is the combined treatment of bio fertilizers $\mathrm{EM}+\mathrm{M}+\mathrm{ph}$ and 10 ton $\mathrm{fed}^{-1}$ from compost. Meanwhile, the highest values of $\mathrm{NO}_{3}-\mathrm{N}$ content was obtained from the control treatment of bio fertilizers with applying 5 ton $\mathrm{fed}^{-1}$ from biochar.

\section{CONCLUSION}

It could be concluded that the use of 10 ton fed $^{-1}$ compost fertilizer with applying microbien + phosphosien+ EM could enhance significantly the yield , nutrient contents and quality of cucumber under an organic farming system .

\section{REFERENCES}

Abd El-Hameed (2013). Response of carrot (Daucus carota) to mineral, organic and biofertilization. Ph.D. Thesis, Fac. of Agric., Mansoura Univ., Egypt.
Abou-El-Hassan, S. ; M.A.A. Abdrabbo and A.H. Desoky (2014). Enhancing organic production of cucumber by using plant growth promoting rhizobacteria and compost tea under sandy soil condition. Res. J. of Agric. and Bio. Sci., 10(2): 162-169.

Abu El-Fotoh, H.G. ; A.A. Abd EL-Magid and R.E. Knany (2000). Effect of biofertilization on sugar beet yield, quality and optimization of the chemical fertilizers. Proc. $9^{\text {th }}$ Conf. of Agron., 12 Sept. 2000, Minufiya Univ., II: 561-567.

Arafa, A. A.; S. F. Hussien and H. S. Mohamed (2012). Response of tuber yield quality and quality of potato plants and its economic consideration to certain bioregulators or effective microorganisms under potassium fertilization. J. Plant Production, Mansoura Univ., 3(1): 131-150.

Ashraf, A.; I. Ahmad; M.M. Yousaf and B. Yousaf (2016). A review on organic farming for sustainable agricultural production. Pure Appl. Biol. 5 (2), 277-286.

Ayuso, M.; T. Hernandez; C. Garcia and J. A. Pascual (1996). Stimulation o.f

barley growth and nutrient absorption by humic substances originating from various organic materials. Bioresource Tech., 57: 251-257.

Belay, A. ; A.S. Classens ; F.C. Wehner and J.M. De Beer (2001). Influence of residual manure on selected nutrient elements and microbial composition of soil under long-term crop rotation. S. Afric. J. Plant Soil., 18: 1-6.

Black, C. A. (1965). "Methods of Soil Analysis." Part 1 and 2 USA, Madison,Wiscansin

Cakmakci, R. ; F. Kantar and O.F. Algur (1999). Sugar beet and barley yields in relation to Bacillus polymyxa and Bacillus megaterium var. phosphaticum inoculation. J. of Plant Nutrition and Soil Sci., 162 (4): 437-442.

Dimitri, C. ; L. Kemp ; J. Sooby and E. Sullivan (2012). Organic farming for health and prosperity. Organic Farming Research Foundation (OFRF), August 2012, pp: 1-75.

Downie A, Crosky A, Munroe P (2009). Physical properties of biochar. In: J Lehmann, S Joseph (eds) Biochar for Environmental Management: Science and Technology. Earthscan.

El-Ghabdan,E.A.;E.A.M.Ghallab and A.F. Abdlwahab (2002) . Effect of organic fertilizer (Biogreen) and bio fertilization on growth, yield and chemical composition of Marjoram plants growth undr newly reclaimed soil conditions, $2^{\text {nd }}$ Congress of Recent Technologies in Agriculture ,2:334-361.

Fahmy, M.A.M. (2012). Effect of some treatments on growth, yield and fruit chemical composition of melon and cucumber crops under sandy soils conditions. M. Sc. Thesis, in Agricultural Sciences (Vegetable Crops), Faculty of Agriculture, Cairo University. 
García-Gil, J.C., Ceppi, S.B., Velasco, M.I., Polo, A., Senesi, N., 2004. Long term effects of amendment with municipal solid waste compost on the elemental and acidic functional group composition and pH-buffer capacity of soil humic acids. Geoderma. 121, 135-142.

Gomez, K. A. and A. A. Gomez (1984)." Statistical Procedures For Agricultural Research". John Wiley and Sons. Inc. New York.

Han, H.S. ; K. Supanjani and D. Lee (2006). Effect of co-inoculation with phosphate and potassium solubilizing bacteria on mineral uptake and growth of pepper and cucumber. Plant Soil Environ., 52(3): 130-136.

Hesse, P. R. (1971). A Textbook of Soil Chemical Analysis. John Murray Ltd, London. pp. 520.

Isfahani, F.M. and H. Besharati (2012). Effect of biofertilizers on yield and yield components of cucumber. J. of Biology and Earth Sci., 2(2): 83-92.

Jackson, M. L. (1967). "Soil Chemical Analysis" Prentica Hall Inc, Engleweed Cliffs, N. J.

Kabeel, S. M. A. and N. M. Hasanin (2006). Increasing potato productivity grown in sandy soil through organic and biofertilizers application. J. Agric. Sci. Mans. Univ., 31 (2): 951-962.

Mahmoud, E. ; N. Abd El- Kader ; P. Robin ; N. AkkalCorfini and L. Abd El-Rahman (2009). Effects of different organic and inorganic fertilizers on cucumber yield and some soil properties. World J. of Agric. Sci., 5 (4):408-414.

Moemenpour, F. and E. Karami (2015). Effects of methanol foliar spray and bio-fertilizers application on fruit yield of greenhouse cucumbers. Intern. J. of Agric. Policy and Res., 3(10): 382-387.

Nair, A. and M. Ngouajio (2010). Integrating rowcovers and soil Amendments for organic cucumber production: implications on crop growth, yield, and microclimate. Hort. Sci., 45(4):1-9.

Natsheh, B. and S. Mousa (2014). Effect of organic and inorganic fertilizers application on soil and cucumber (Cucumis sativa L.) plant productivity. Intern. J. of Agric. and Forestry, 4(3): 166-170.

Olle, M. (2015). The influence of effective microorganisms on the growth and nitrate content of vegetable transplants. J. of Advanced Agric. Tech., 2(1): 25-28.
Peterburgski, A. V. (1968). "Hand Book Of Agronomic Chemistry". Kolas publishing House, Moscow, (in Russian), pp. 29-86.

Polat, E.; H. B. Uzun; B. Topçuolu; K. Önal; A. N. Onus and M. Karaca (2009). Effects of spent mushroom compost on quality and productivity of cucumber (Cucumis sativus L.) grown in greenhouses. African J. of Biotech., 8(2): 176-180.

Rashed,N.M.(2002).Effect of fertilization on the growth and storability of some aramotic plants. M.Sc.Thesis,Fac. Agric. Kafr EL-Sheikh , Tanta Univ.

Rudich, J. and A. Peles (1976). Sex expression in watermelon as affected by photoperiod and temperature. Sci. Hort., 5(4): 339-344.

Ryan, J.,S. Garabet, K. Harmsen, and A. Rashid,(1996). A Soil and Plant Analysis Manual Adapted for the West Asia and Africa Region. ICARDA, Aleppo, Syria.140pp.

Saeed, K.S. ; S.A. Ahmed ; I.A. Hassan and P.H. Ahmed (2015). Effect of bio-fertilizer and chemical fertilizer on growth and yield in cucumber (Cucumis sativus L.) in green house condition. American-Eurasian J. Agric. \& Environ. Sci., 15 (3): 353-358

Saleh, M. M., M. Fayza, A. Darwish and M. H. Mona (2007). Effect of different types and levels of organic fertilizers combined with biofertilizers on growth and yield of tomato grown in sandy soil, J. Agric. Sci. Mans. Univ; 32 (7): 5553-5568.

Singh, I. P. (1988). A rapid method for determination of nitrate in soil and plant extracts. Plant and soil, 110: $137-139$.

Talha, N. I. (2013). Evaluation of different compost sources to improve some soil properties under wheat and maize crops rotation. J. Soil Sci. and Agric. Eng., Mansoura Univ., 4(8): 677 - 693.

Woodward, D. (2003). Soil and sustainability: Effictive microorganisms as regenerative systems in earth healing. M. Sc. Dissertation. Brighton.

Yadav, S. K.; S. Babu; M. K. Yadav; K. Singh; G. S. Yadav and S. Pal (2013). A Review of Organic Farming for Sustainable Agriculture in Northern India. International Journal of Agronomy. 2013. $1-8$.

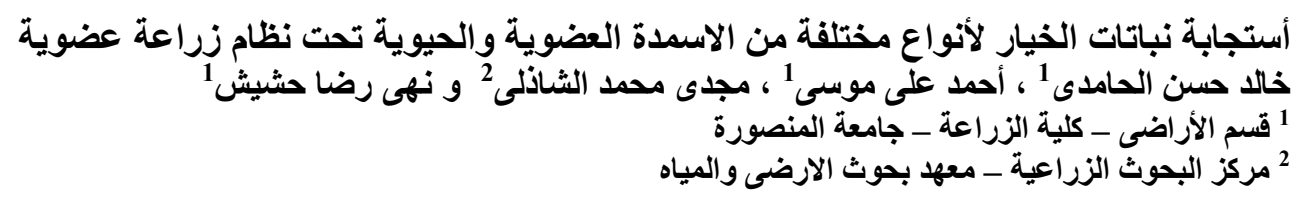

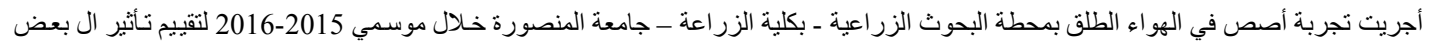

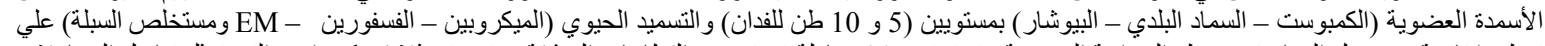

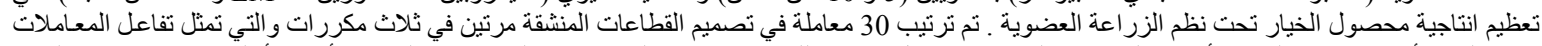

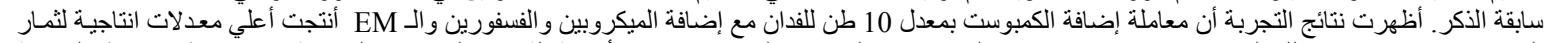

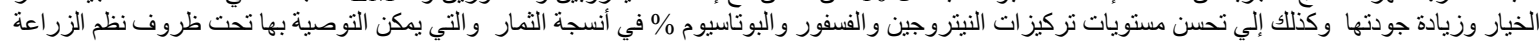

